\title{
Kabyle Language
}

National Cancer Institute

\section{Source}

National Cancer Institute. Kabyle Language. NCI Thesaurus. Code C153966.

An Afro-Asiatic Berber language spoken by the Kabyle people in the north and northeast of Algeria. 